\title{
Wanita Karier Dalam Pandangan Islam \\ Husnussa'adah
}

\author{
Institut Parahikma Indonesia (IPI) Gowa \\ Husnussaadah84@gmail.com
}

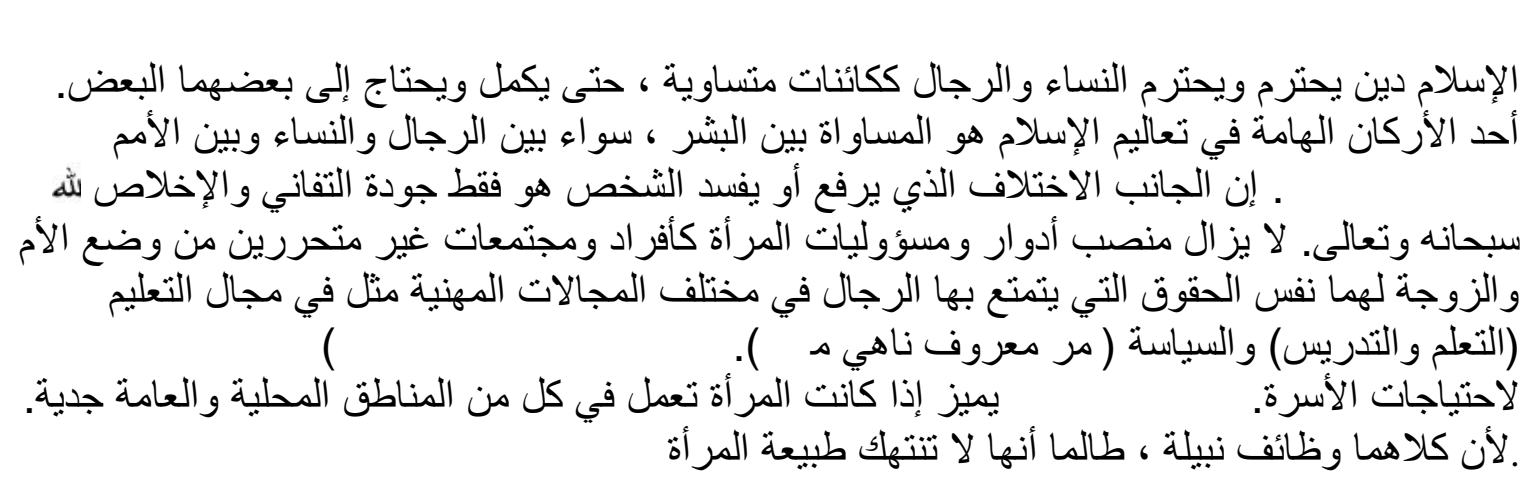

\section{Pendahuluan}

Salah satu prinsip pokok ajaran Islam adalah persamaan antar manusia, baik antara pria maupun wanita, bangsa, suku, dan keturunan. Perbedaan di antara mereka di hadapan Tuhan Yang Maha Esa hanyalah nilai pengabdian dan ketakwaannya. Banyak ayat al-Qur'an menunjukkan peluang untuk meraih prestasi maksimum tidak ada pembedaan antara laki-laki dan perempuan ditegaskan secara khusus dalam beberapa ayat, sebagai berikut :

Sebagaimana firman Allah dalam Qs. Al-Imran (3) : $195^{20}$

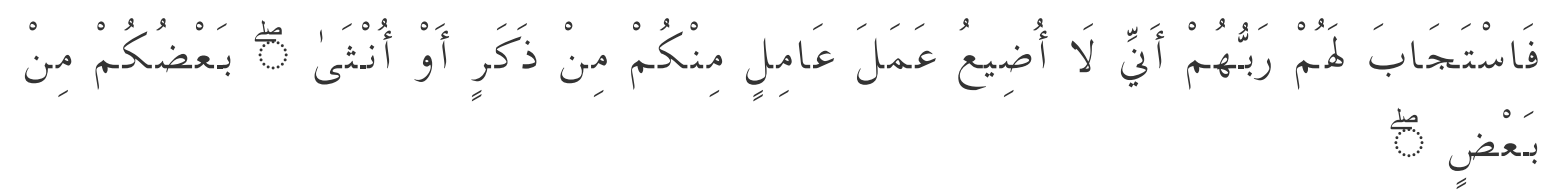

Terjemahan :

“...Sesungguhnya Aku tidak menyia-nyiakan amal orang yang beramal di antara kamu, baik laki-laki maupun perempuan (karena) sebagian kamu adalah (keturunan) dari sebagian yang lain,... ${ }^{21}$ ",

QS. An Nahl [16]: 97).

\footnotetext{
${ }^{20}$ Departemen agama RI, Al-Qur'an Dan Terjemahan Special F or Women, (Syamil Qur'an: Jakarta, 2009), h. 76

${ }^{21}$ Maksudnya adalah sebagaimana laki-laki berasal dari laki-laki dan perempuan, maka demikian pula sebaliknya perempuan berasal dari laki-laki dan perempuan, keduanya sama-sama manusia, tak ada kelebihan yang satu dengan yang lain tentang penilaian iman dan amalnya.
} 
An-Nisa', Volume XI Nomor 2 Desember 2018

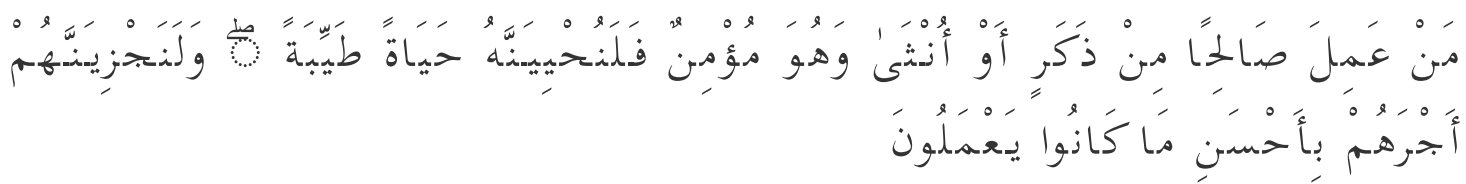

"Barangsiapa mengerjakan amal saleh baik pria maupun wanita dalam keadaan beriman, maka sesungguhnya akan Kami berikan kepadanya kehidupan yang baik dan sesungguhnya akan Kami beri balasan kepada mereka dengan pahala yang lebih dari apa yang telah mereka kerjakan" (QS. An Nahl [16]: 97).

Qs. An-Nisa (4) : 124 .

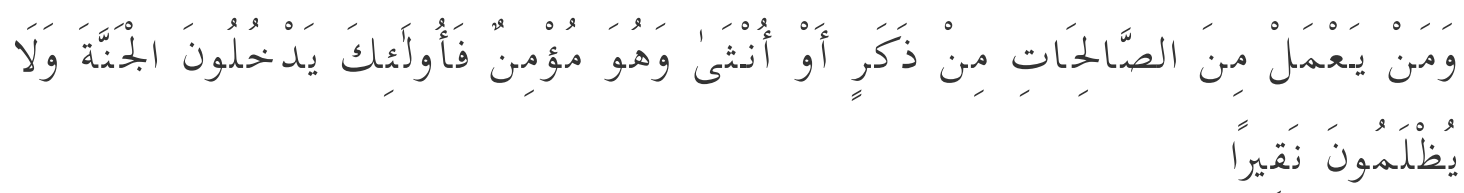

Terjemahan :

Dan barang siapa yang mengerjakan amal kebajikan, baik laki-laki maupun perempuan sedang dia beriman, maka mereka itu akan masuk ke dalam surga dan mereka tidak didzalimi sedikit pun.

Berdasarkan keterangan ayat di atas, dapat dipahami bahwa Islam mengangkat derajat seorang wanita dan memberinya kebebasan, kehormatan, serta kepribadian yang independen. Bahkan dalam Al-Qur'an tidak ditemukan ayat yang menunjukkan keutamaan seseorang karena faktor jenis kelamin atau karena keturunan, suku bangsa tertentu, kemandirian dan otonomi perempuan dalam tradisi Islam sejak awal terlihat begitu sangat kuat.

Dengan demikian, Islam mengangkat derajat dan posisi perempuan. Nabi Saw berusaha melepaskan belenggu tradisi Jahiliyah pada saat itu, yaitu mengangkat harkat perempuan. Ini terlihat dalam ayat-ayat Al-Quran dan perilaku Nabi terhadap perempuan, baik isteri-isterinya, anak-anaknya maupun sahabatnya. Konsep perempuan dalam Al-Quran secara jelas dan tegas menyatakan posisi dan peran perempuan setara laki-laki. Yang dimuliakan di sisi Allah bukan perbedaan jenis kelamin, akan tetapi nilai ketakwaan.

Dewasa ini kesadaran akan kesejajaran jender semakin meningkat. Wanita telah banyak merambah kehidupan publik yang selama ini didominasi pria. Wanita telah banyak menuntut dan menyuarakan apa-apa yang sudah menjadi haknya. Di antaranya adalah hak memperoleh persamaan dengan kaum pria dalam segala hal, termasuk juga hak untuk turut aktif dalam kegiatan-kegiatan publik, bekerja di luar rumah, dan banyak di antara mereka menjadi wanita karier. Ada yang memang dengan terpaksa bekerja untuk menambah penghasilan keluarga atau 
malah menjadi tulang punggung keluarga, atau sekedar menunjukkan eksistensi. Yang terakhir memahami, bisa melakukan apa saja yang dilakukan pria. Dalihnya, kesetaraan jender. ${ }^{22}$ Dari latar belakang tersebut maka penulis mengidentifikasikan permasalahan dalam tulisan ini yaitu Bagaimana pandangan Islam jika wanita bekerja di ranah public sebagai wanita karier?

\section{Pengertian Wanita Karier}

Dalam Kamus Besar Bahasa Indonesia, "wanita” berarti perempuan dewasa. Sedangkan "karier" Kata karier mempunyai dua pengertian: pertama, karier berarti pengembangan dan kemajuan dalam kehidupan, pekerjaan, dan sebagainya; kedua, karier berarti juga pekerjaan yang memberikan harapan untuk maju. ${ }^{23}$ Ketika kata "wanita" dan "karier" disatukan, maka kata itu berarti wanita yang berkecimpung dalam kegiatan profesi dan dilandasi keahlian pendidikan tertentu. $^{24}$

Wanita karier berarti wanita yang berkecimpung dalam kegiatan profesi seperti bidang usaha, perkantoran, dan sebagainya dilandasi dengan pendidikan keahlian seperti keterampilan, kejujuran dan sebagainya yang menjanjikan untuk mencapai kemajuan. ${ }^{25}$ Wanita karier yang adalah wanita yang menekuni dan mencintai sesuatu atau beberapa pekerjaan secara penuh dalam waktu yang relatif lama, untuk mencapai suatu kemajuan dalam hidup, pekerjaan atau jabatan. ${ }^{26}$ Umumnya karier ditempuh oleh wanita diluar rumah sehingga wanita karier tergolong mereka yang berkiprah disektor public.

Wanita karier adalah mereka yang hasil karyanya akan dapat menghasilkan imbalan keuangan $^{27}$ dari penyataan tersebut dapat dikelompokkan alasan seorang wanita berkiprah disektor public adalah sebagai berikut : Pertama, Mereka yang bekerja untuk penyaluran hobby,

\footnotetext{
${ }^{22}$ Jender adalah sebuah pendefinisian sosial yang menunjuk pada perbedaan karakteristik lelaki dan perempuan. Karakteristik ini merupakan bentukan dari budaya manusia. Lihat Indarswari, "Fenomena Kawin Muda dan Aborsi; Gambaran Kasus", dalam Sayiq Hasyim (ed.), Menakar Harga Perempuan, cet. ke-2 (Bandung: Mizan, 1999), h. 133.

${ }^{23}$ Depdikbud, Kamus Besar Bahasa Indonesia (Jakarta Gramedia Pustaka Utama, 2008), h. 372

${ }^{24}$ Ajat Sudrajat, Fikih Aktual Membahas Problematika Hukum Islam Kontemporer, (STAIN Ponorogo Press, 2008), h. 103.

${ }^{25}$ Siti Muri'ah, Nilai-Nilai Pendidikan Islam dan Wanita Karir;(Semarang: Rasail Media Group. 2011), h. 29

${ }^{26}$ Siti Muri'ah, Nilai-Nilai Pendidikan Islam dan Wanita Karir, h. 30

${ }^{27}$ A. Hafiz Anshary A.Z. dan Huzaimah T. Yanggo (ed.), Ihdad Wanita Karir, dalam Problematika Hukum Islam Kontemporer (II), (Cet. III, Jakarta : Pustaka Firdaus, 2002), h. 11
} 
pengembangan bakat dan meningkatkan karir; Kedua, Mereka yang bekerja untuk memenuhi kebutuhan hidup atau karena tekanan ekonomi, dengan kata lain untuk perbaikan sosial.

Keikutsertaan wanita dalam kegiatan profesi, harus mempunyai tujuan yang baik, dan apapun profesi yang dijalankan tidak mengganggu hak suami dan anakn-anaknya karena

mengurus rumah tanga adalah tangung jawab utama kaum wanita. ${ }^{28}$ Jadi yang dimaksudkan wanita karier adalah wanita yang memerankan dirinya sebagai seorang yang menekuni profesi tertentu dalam rangka memenuhi suatu kebutuhan, disamping perannya sebagai istri dan ibu rumah tangga, sehingga sering disebut wanita berperan ganda.

\section{Peran dan Tanggung Jawab Wanita dalam Islam}

a. Wanita sebagai Ibu

Islam memandang dan memposisikan wanita sebagai ibu ditempat yang luhur dan sangat terhormat. Ibu adalah satu diantara orang tua yang yang mempunyai peran yang sangat penting dalam kehidupan setiap individu. ${ }^{29}$ Posisi perempuan sebagai ibu dalam Islam sangat tinggi, ia berhak mendapatkan penghormatan tiga kali besar dari penghormatan anak kepada ayahnya. ${ }^{30} \mathrm{Di}$ tangan ibulah setiap individu dibesarkan dengan kasih sayang yang tidak terhingga. Secara tegas Alquran memerintahkan setiap manusia untuk menghayati dan mengapresiasi ibu atas jasajasanya dengan berbuat baik kepadanya.

Firman Allah dalam Q.S al Lukman (31): 14

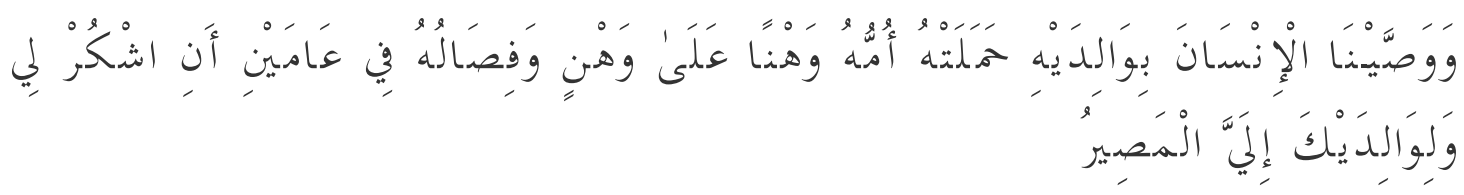

Terjemahnya:

Dan Kami perintahkan kepada manusia (berbuat baik) kepada dua orang ibu-bapanya; ibunya telah mengandungnya dalam Keadaan lemah yang bertambah-tambah, dan menyapihnya dalam dua tahun. Bersyukurlah kepadaku dan kepada dua orang ibu bapakmu, hanya kepada-Kulah kembalimu.

Imam Al-Gazali menjelaskan tugas dan kewajiban orang tua terhadap ananknya, yaitu:

\footnotetext{
${ }^{28}$ Sobri Marsi al-Faqi, Solusi Problematika Rumah Tangga, (Surabanya : Sukses Publishing, 2015), h. 64

${ }^{29}$ Siti Muri'ah, Nilai-Nilai Pendidikan Islam dan Wanita Karir, h. 145

${ }^{30}$ Siti Musdah Mulia, Muslimah Sejati Menempuh Jalan Islami Meraih Ridha Ilahi, (Bandung: Marja, 2011), hal. 140
} 


\section{An-Nisa', Volume XI Nomor 2 Desember 2018}

1. Harus mendidik dan memperbaiki akhlaknya serta memeliharanya dari lingkungan yang jelek

2. Tidak membiasakan dengan perhiasan dengan kemewahan, harus mencegahnya mengambil sesuatu dengan sembunyi-sembunyi, karena hal itu menunjukkan sifat kejelekannya.

3. Hendaknya ibu mengerjakan untuk patuh kepada orang tua, gurunya dan orang yang lebih tua dalam keluarga. ${ }^{31}$

Sebagaimana dalam pendidikan Islam bahwa keluarga merupakan pendidikan yang pertama dan utama bagi anak maka orang tua berkewajiban mengasuh dan mendidik anak menjaga dari segala macam bahaya, menjaga keselamatan dan kesehatan lahir batin, jasmani dan rohaniah. Mendidiknya agar menjadi manusia yang berguna dan bahagia di dunia maupun di akhirat. Memberinya pelajaran dengan ilmu yang bermanfaat, agar ia menjadi sempurna, berilmu dan beragama beramal dan beribadah dan dapat pula berdiri sendiri, mengarungi hidup yang penuh keyakinan.

\section{b. Wanita sebagai Istri}

Peran lain wanita dalam kehidupan sehari-hari adalah sebagai istri. Islam memuliakan seorang istri dengan penghormatan yang tidak pernah diterima oleh para istri dari umat-umat lainnya. Islam menjadikan pernikahan sebagai salah satu tanda-tanda kekuasaan Allāh swt., sebagaimana dalam QS. Ar Rum (30) : 21

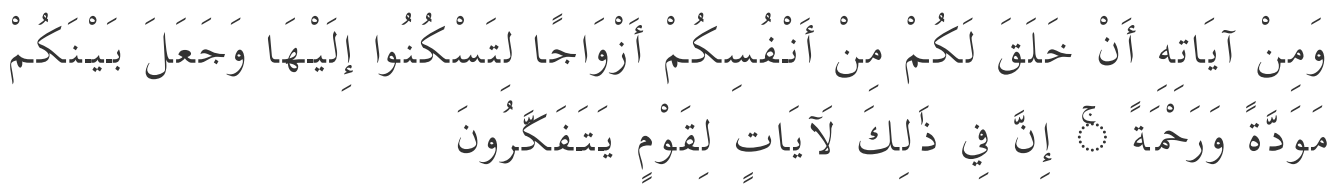

Terjemahan :

Dan di antara tanda-tanda kekuasaan-Nya ialah Dia menciptakan untukmu istri-istri dari jenismu sendiri, supaya kamu cenderung dan merasa tenteram kepadanya, dan dijadikan-Nya diantaramu rasa kasih dan sayang. Sesungguhnya pada yang demikian itu benarbenar terdapat tanda-tanda bagi kaum yang berfikir.

Suami dan istri adalah sepasang makhluk manusia yang atas dasar cinta kasih suci mengikat diri dalam jalinan nikah. Keduanya saling melengkapi dan saling membutuhkan. Q.S. al-Baqarah(2): 87 menyatakan:

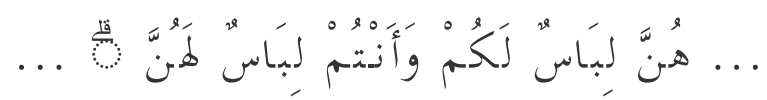

\footnotetext{
${ }^{31}$ Abubakar Muhammad, Membangun Manusia Seutuhnya Menurut Al-Quran (Surabaya: Al-Ikhlas, t.th.), h. 258.
} 
Terjemahan :

"Mereka adalah Pakaian bagimu, dan kamupun adalah pakaian bagi mereka.."

Berdasarkan ayat tersebut dapat dipahami bahwa antara suami dengan istri kedekatannya dan fungsinya adalah bagaikan pakaian yang melekat tubuh pemakainya, saling menutupi kekurangan pasangannya dan saling melindungi. Islam memandang perkawinan melalui jalinan pernikahan dalam rangka mensejahterakan manusia (baik pria maupun wanita) serta menjamin kelangsungan hidup manusia melalui reproduksi dan regenerasi dalam sistem yang sehat.

\section{c. Wanita sebagai anggota Masyarakat}

Hidup bermasyarakat adalah suatu keharusan bagi manusia, dikatakan demikian karena manusia sulit untuk menjauhkan diri dari masyarakatnya, tidak dapat hidup tanpa bantuan orang lain. Wanita sebagai mana halnya dengan laki laki mempunyai tanggung jawab dan kewajiban untuk ikut memelihara ketentraman dan keamanan hidup masyarakat dan mengaktifkan diri dari dalam setiap bentuk kegiatan yang ada pada masyarakat.

Dalam kehidupan bermasyarakat, banyak hal yang menjadi hak dan kewajiban setiap anggotanya. Hak dan kewajiban itu harus dijunjung tinggi oleh setiap anggota dalam kegiatan dan kehidupan sehari-hari. Al-Quran sebagai rujukan prinsip dasar masyarakat Islam menunjukkan bahwa pria dan wanita diciptakan dan satu nafs (living entity), di mana yang satu tidak memiliki keunggulan terhadap yang lain dan mempunyai hak dan kewajiban sama. Ajaran Islam tidak secara skematis membedakan faktor-faktor perbedaan laki-laki dan perempuan, tetapi lebih memandang kedua insan tersebut secara utuh. Antara satu dengan yang lainnya secara biologis dan sosio-kultural saling memerlukan dan dengan demikian antara satu dan lain masingmasing mempunyai peran. ${ }^{32}$ Meninggalkan tanggungjawab atas pembinaan dan pengembangan masyarakat disekelilingnya, sama saja merelakan kehancuran masyarakatnya. Sehubungan dengan hal ini, Allah Swt. Berfirman dalam QS. At-Taubah (9):71:

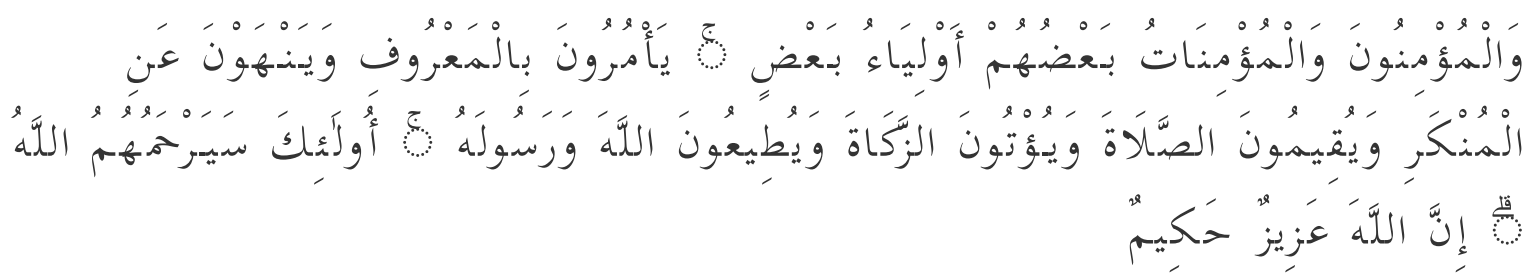

Terjemahnya:

\footnotetext{
${ }^{32}$ Nasaruddin Umar, Kodrat Perempuan Dalam Islam, (Cet. I; Jakarta: Lembaga Kajian Dan Jender, 1999), h. 22.
} 


\section{An-Nisa', Volume XI Nomor 2 Desember 2018}

Dan orang-orang yang beriman, lelaki dan perempuan, sebahagian mereka (adalah) menjadi penolong bagi sebahagian yang lain. Mereka menyuruh (mengerjakan) yang ma'ruf, mencegah dari yang munkar, mendirikan shalat, menunaikan zakat dan mereka taat pada Allah dan RasulNya. mereka itu akan diberi rahmat oleh Allah; Sesungguhnya Allah Maha Perkasa lagi Maha Bijaksana.

Perempuan dalam kehidupan bermasyarakat boleh berperan aktif selama hal itu sesuai dengan kodratnya, misalnya dalam bidang sosial, politik, pendidikan dan pengajaran, pemeliharaan kesehatan masyarakat. Negara dan bangsa kita membutuhkan kehadiran perempuan salihah, dengan keterampilan dan keahlian yang dimilikinya, sehingga dengan paduan tersebut maka dapat membimbing dan mengarahkan masyarakat kepada hal-hal yang baik.

\section{Wanita Karier Dalam Pandangan Islam}

Bekerja dalam Islam merupakan hak setiap muslim, tidak ada perbedaan antara laki-laki dan perempuan, pandai dan bodoh, kaya dan miskin. Bekerja terbuka bagi siapa saja selama pekerjaan tersebut tidak mendatangkan bahaya pada dirinya. Bekerja secara professional dapat katakana bawa seseorang melaksanakan pekerjaannya berasarkan ilmu pengetahuan, keahlian, keterampilan sesuai dengan ketentuan yang berlaku serta konsisten. Islam menfasilitasi manusia untuk belajar dan berlatih mengaktualisasika segenap potensi yang dimilikinya, baik yang bersifat fisik (jasmaniah) maupun non fisik (rohaniah) yang profilnya digambarkan oleh Allah dalam al-Qur'an sebagai sosok Ulil Albab, sebagai manusia paripurna yaitu manusia yang beriman, berilmu dan selalu produktif mengerjakan amal shaleh sesuai dengan tuntunan ajaran islam. ${ }^{33}$

Karier sangat diperlukan wanita agar bisa mewujudkan jati diri dan membangun kepribadiannya. Sebab dalam hal ini wanita tetap bisa mewujudkan jati dirinya secara sempurna dengan berprofesi sebagai ibu rumah tangga, sambil berpartisipasi aktif dalam kegiatan sosial atau politik.

Seorang wanita boleh bekerja jika ada salah satu dari sejumlah keadaan yang membolehkan wanita bekerja diluar rumah sehingga dikatakan bahwa wanita karier itu harus memenuhi syaratsyarat tertentu. Dengan demikian, keluarnya wanita dari rumah untuk bekerja itu tidak berakibat buruk bagi dirinya, suaminya, anak-anaknya dan masyarakatnya. Diantara persyaratan yang telah ditetapkan para ulama fiqih bagi wanita adalah:

\footnotetext{
${ }^{33}$ Heri Gunawan, Pendidikan Islam (Kajian teoritis dan Pemikiran Tokoh),(Rosdakarya: Jakarta : 1992), h. 16.
} 
a) Persetujuan suami

b) Menyeimbangkan tuntutan rumah tangga dan tuntutan kerja

c) Pekerjaan itu tidak menimbulkan khalwat

d) Menghindari pekerjaan yang berbahaya bagi diri wanita dan masyarakat.

e) Menjauhi segala sumber fitnah.

f) Memperpanjang pakaiannya hingga menutupi kedua kakinya dan menutupkan kerudung ke kepalanya sehingga tertutup bagian leher, bagian atas dada, dada dan wajahnya. $^{34}$

Selain syarat yang ditetapkan para ulama, terdapat beberapa garis panduan yang harus diikuti oleh setiap wanita bekerja antara lain:

1. Bertanggung jawab terhadap keluarga.

2. Menjaga kehormatan diri.

3. Mengawal perlakuan dan pergaulan.

4. Bertanggung jawab dalam setiap tindakan. ${ }^{35}$

Jika kembali menelaah keterlibatan perempuan dalam pekerjaan pada masa awal Islam, maka tidaklah berlebihan jika dikatakan bahwa Islam membenarkan mereka aktif dalam berbagai aktivitas. Para wanita boleh bekerja dalam berbagai bidang, di dalam ataupun di luar rumahnya, baik secara mandiri maupun bersama orang lain, dengan lembaga pemerintah ataupun swasta, selama pekerjaan tersebut dilakukannya dalam suasana terhormat dan sopan, selama mereka dapat memelihara agamanya, serta dapat menghindari dampak-dampak negatif dari pekerjaan tersebut terhadap diri dan lingkungannya.

Seorang wanita karier harus memiliki basis pendidikan yang bisa mewujudkan dua hal utama, disamping tujuan-tujuan umum pendidikan Islam, juga bisa mengaturrumah tangga dan bisa mengasuh anak-anak dengan penuh dedikasi. ${ }^{36}$ Demikian demikian seorang wanita karir

\footnotetext{
${ }^{34}$ Lihat Husein Syahatah, Ekonomi Rumah Tangga Muslim, (Gema Insani: Jakarta), h. 144-149.

${ }^{35}$ Bushrah Basiron, Wanita Cemerlang (Johor Bahru: Universiti teknologi Malaysia, 2006). h 74.

${ }^{36}$ Mahmud Muhamad al_jauhari dan Muhammmad Abdul Hakim Khayyal, Membangun Keluarga Qur'ani; Panduan Untuk wanita Muslimah (Jakarta: Amanah, 2005), h. 92.
} 


\section{An-Nisa', Volume XI Nomor 2 Desember 2018}

mampu menjalankan profesi yang digelutinya dengan penuh dedikasi jika memang harus bekerja entah karena kebutuhan pribadi, kebutuhan keluarga atau kebutuhan sosial.

\section{Kesimpulan}

Beberapa ayat al-Qureān yang telah dipaparkan cukup menjadi bukti bahwa ajaran Islam menjunjung tinggi hak-hak wanita. Islam memberikan motivasi yang kuat agar para wanita mampu berkarier di segala bidang sesuai dengan kodrat dan martabatnya. Dalam berkarir dianjurkan bagi wanita harus bisa menempatkan waktunya dalam segala hal yang berkaitan dengan kariernya dan harus bisa mengatur rumah tangganya agar kedua tanggung jawabnya bisa dia laksanakan dengan baik.

Wanita karir adalah wanita yang bekerja di luar rumah dengan berbagai profesi yang berbeda-beda. wanita karir di dalam masyarakat saat ini sudah menjadi kebutuhan bagi masyarakat dan bagi pelaku perempuan karir itu sendiri. Masyarakat mulai membuka diri untuk wanita karir dengan menyatakan bahwa wanita karir diperbolehkan oleh agama selama tidak melanggar fitrah sebagai wanita.

\section{Daftar Pustaka}

Al_jauhari Mahmud Muhamad. dan Muhammmad Abdul Hakim Khayyal, Membangun Keluarga Qur'ani; Panduan Untuk wanita Muslimah, Jakarta : Amanah, 2005.

al-Faqi, Sobri Marsi. Solusi Problematika Rumah Tangga, Surabanya : Sukses Publishing, 2015.

Anshary, A. Hafiz dan Huzaimah T. Yanggo (ed.), Ihdad Wanita Karir, dalam Problematika Hukum Islam Kontemporer (II), (Cet. III, Jakarta : Pustaka Firdaus, 2002.

Basiron, Bushrah. Wanita Cemerlang (Johor Bahru: Universiti teknologi Malaysia, 2006.

Depdikbud, Kamus Besar Bahasa Indonesia (Jakarta Gramedia Pustaka Utama, 2008.

Gunawan, Heri. Pendidikan Islam; Kajian teoritis dan Pemikiran Tokoh, Rosdakarya: Jakarta : 1992.

Hasyim, Sayiq (ed.), Menakar Harga Perempuan, cet. ke-2 (Bandung: Mizan, 1999. 
An-Nisa', Volume XI Nomor 2 Desember 2018

Muhammad, Abubakar. Membangun Manusia Seutuhnya Menurut Al-Quran Surabaya: AlIkhlas, t.th.

Mulia, Siti Musdah Muslimah Sejati Menempuh Jalan Islami Meraih Ridha Ilahi, Bandung: Marja, 2011.

Muri'ah, Siti. Nilai-Nilai Pendidikan Islam dan Wanita Karir; Semarang: Rasail Media Group. 2011.

Sudrajat, Ajat. Fikih Aktual Membahas Problematika Hukum Islam Kontemporer, STAIN Ponorogo Press, 2008.

Syahatah, Husein. Ekonomi Rumah Tangga Muslim, Gema Insani: Jakarta. 2008.

Umar, Nasaruddin. Kodrat Perempuan Dalam Islam, Cet. I; Jakarta: Lembaga Kajian Dan Jender, 1999. 